\title{
ANALISA FAKTOR YANG PENTING DARI DIMENSI ELECTRONIC WORD OF MOUTH (EWOM) BAGI KONSUMEN DALAM MEMILIH HOTEL DI SITUS ONLINE TRAVEL AGENT (OTA)
}

\author{
Vania Karunia Utami ${ }^{1}$, Daniel Tanujaya ${ }^{1}$, Regina Jokom ${ }^{1 *}$ \\ ${ }^{1}$ Program Manajemen Perhotelan, Fakultas Ekonomi, Universitas Kristen Petra \\ Jl. Siwalankerto 121-131, Surabaya \\ E-mail: m33411032@john.petra.ac.id; m33411100@john.petra.ac.id, regina@peter.petra.ac.id
}

* Korespondensi penulis

\begin{abstract}
Abstrak: Online Travel Agent (OTA) adalah e -commerce yang memudahkan pelanggan untuk membeli berbagai produk pariwisata (mis kamar hotel). Selama proses seleksi Hotel di OTA, pelanggan cenderung mencari informasi dari Electronic Word of Mouth ( eWOM ) atau ulasan. eWOM memiliki 13 dimensi yang dianalisis berdasarkan kepentingannya. Penelitian ini dilakukan untuk mengetahui faktor-faktor yang penting bagi pelanggan ketika memilih sebuah hotel di OTA. Jenis penelitian ini adalah deskriptif kuantitatif dengan menggunakan analisis faktor exploratory. Hasil analisis menunjukkan bahwa ada 3 faktor penting: isi review, kredibilitas sumber, gaya penulisan dan peringkat rekomendasi. Isi ulasan sepenuhnya merupakan faktor yang paling penting di antara mereka 3 faktor menurut kontribusinya dalam menseleksi Hotel.
\end{abstract}

Kata kunci: Electronic word of mouth, agen perjalanan online, pilihan hotel

\begin{abstract}
Online Travel Agent (OTA) is an e-commerce which facilitates its customers to buy various tourism products (e.g. hotel rooms). During hotel selection process on OTA, customers tend to look for information such as Electronic Word of Mouth (eWOM) or review. eWOM has 13 dimensions that were analyzed based on its importance. This research is conducted to find out which factors are important for customers when selecting a hotel on OTA. The research type is quantitative descriptive using exploratory factor analysis. The analysis showed that there are 3 important factors: content of review, source credibility, writing style and recommendation rating. Content of review is the most important factors among those 3 factors according to its contribution in hotel selection.
\end{abstract}

Keywords: Electronic word of mouth, online travel agent, hotel choice.

\section{PENDAHULUAN}

Di era globalisasi, internet telah menjadi lifestyle bagi banyak konsumen, salah satunya untuk berbelanja. Sejak 2013, jumlah digital shopper atau pembeli online terus meningkat dimulai dari 4,6 juta orang dan diprediksi pada tahun 2016, jumlah pembeli online akan mencapai 8,7 juta orang (Rizkia, 2015, para 2) Website yang menyediakan layanan transaksi berbelanja atau berdagang secara online disebut dengan e-commerce. Menurut Brynjolfsson dan Smith (2000) berbelanja secara online memiliki karakteristik yang berbeda dengan berbelanja secara tradisional karena mampu menawarkan produk atau jasa yang lebih banyak serta akses dan kenyamanan yang tidak dibatasi oleh waktu dan ruang. Namun Grewal, Munger, Iyer, dan Levy (2003) menyatakan bahwa berbelanja secara online juga memiliki kelemahan yaitu adanya resiko ketidakpastian kualitas yang belum tentu sama dengan ekspektasi konsumen. Peterson dan Merino (2003) mengatakan, untuk mengurangi resiko ketidakpastian, konsumen cenderung untuk mencari informasi mengenai produk atau jasa yang akan mereka beli di internet.
Hennig-Thurau dan Walsh (2003) menyatakan internet menyediakan berbagai cara untuk mendapatkan informasi yang berkaitan dengan produk atau jasa dari konsumen lain. Informasi tersebut disebut juga dengan Electronic Word of Mouth (eWOM). Salah satu bentuk dari eWOM adalah online review.

Fitur online review disediakan oleh Online Travel Agent (OTA) sebagai situs e-commerce yang memfasilitasi konsumen untuk membeli produk atau jasa pariwisata. OTA membantu konsumen dalam melakukan pemesanan hotel dengan memberikan informasi-informasi yang terkait seperti harga, lokasi, fasilitas.

Menurut survei yang dilakukan peneliti mengenai perilaku pengguna OTA dalam membaca review dapat diketahui bahwa 84 persen responden membaca online review sebelum memilih hotel yang akan dipesan. Alasan responden membaca review adalah untuk mengetahui respon konsumen lain yang telah menggunakan jasa hotel yang diulas, untuk melihat bagus atau tidaknya kualitas atribut dan pelayanan suatu hotel, untuk mendapatkan kejelasan informasi, dan menambah referensi informasi. Hal ini diperkuat oleh hasil survei yang dilakukan oleh Software 
Advice pada tahun 2013 menyatakan bahwa 46 persen konsumen menggunakan online review sebelum memesan hotel untuk mengidentifikasi hotelhotel yang akan dipertimbangkan, selain itu konsumen juga ingin mempersempit pilihan hotel yang akan dipesan, menemukan harga yang tepat untuk dipesan, dan untuk mengkonfirmasi pilihan akhir hotel yang dipesan (Short, 2014)

Berdasarkan fenomena diatas dapat disimpulkan beberapa pertanyaan yang ingin dijawab melalui penelitian ini, sebagai berikut:

1. Faktor-faktor dari dimensi eWOM apa saja yang penting bagi konsumen dalam memilih hotel di situs OTA?

2. Dari sekian faktor-faktor eWOM yang ada, faktor manakah yang paling berkontribusi bagi konsumen dalam memilih hotel di situs OTA?

\section{TEORI PENUNJANG}

\section{Electronic Word of Mouth (eWOM)}

Menurut Hennig-Thurau, Gwinner, Walsh, dan Gremler (2004), pernyataan positif atau negatif yang dibuat secara potensial dan aktual oleh konsumen yang telah menggunakan produk atau jasa dari suatu perusahaan serta dapat diakses oleh banyak orang dan lembaga-lembaga melalui internet disebut juga dengan electronic word of mouth (eWOM). Jansen, Zhang, Sobel, dan Chowdury (2009) mengatakan bahwa, eWOM menawarkan berbagai cara untuk bertukar informasi, yaitu dapat dilakukan secara rahasia atau anonim, serta memberikan kebebasan geografis dan temporal. eWOM juga memiliki keunikan yang tidak dimiliki WOM, salah satunya yaitu bersifat permanen (Kiecker \& Cowles, 2001).

\section{Dimensi eWOM}

Menurut berbagai sumber eWOM dapat dianalisa dengan menggunakan dimensi-dimensi berikut:

1. Kredibilitas sumber

Kredibilitas sumber adalah persepsi penerima informasi mengenai keahlian sumber (source expertise) dan kepercayaan terhadap informasi (Luo, et al., 2015). Kredibilitas pada umumnya didukung oleh 3 faktor (Teng, Wei Khong, Wei Goh \& Yee, 2014), yaitu:

- Keahlian (expertness), mengacu pada pengetahuan professional (professional knowledge) yang dimiliki komunikator mengenai produk atau jasa.
- Kepercayaan (trustworthiness), adalah tingkat kepercayaan dan penerimaan yang dikembangkan penerima pesan mengenai suatu sumber.

- Pengalaman sumber informasi (source experience), adalah tingkat dimana komunikator merasa familiar dengan produk atau jasa berdasarkan pengalaman aktual dilihat dari sudut pandang penerima eWOM.

2. Kualitas argumen

Menurut Cheung, Lee, dan Rabjohn (2008) kualitas argumen mengacu pada kekuatan persuasif argumen yang melekat pada pesan informasi. Cheung dan Thadani (2010) menyatakan bahwa kualitas argumen dapat dinilai dari beberapa poin berikut:

- Relevansi (relevance), mengacu pada sejauh mana pesan atau informasi dapat diaplikasikan dan berguna dalam proses pembuatan keputusan.

- Aktualitas (timeliness) berkaitan dengan apakah pesan tersebut baru, tepat waktu, dan terkini.

- Keakuratan (accuracy) berkaitan dengan reliabilitas dari pesan atau argumen. Hal itu juga menunjukkan persepsi pengguna bahwa informasi tersebut adalah benar adanya.

- Kelengkapan (comprehensiveness) mengacu pada kemampuan informasi melengkapi kebutuhan pengguna, memiliki nilai-nilai yang dibutuhkan, serta informasi memiliki ke dalaman dan keluasan yang cukup.

3. Tipe review

Tipe review berkenaan pada perbedaan orientasi sebuah review. Menurut Park dan Kim (2008) reviewdapat dikategorikan menjadi 2 tipe yaitu:

- Attribute-centric type

Argumen pendukung evaluasi penulis didasarkan pada atribut teknis dengan penggunaan angka yang menunjukkan tingkatan atribut.

- Benefit-centric type

Penulis secara subyektif menginterpretasikan manfaat setiap atribut dengan caranya tersendiri untuk mengevaluasi produk atau jasa.

4. Recommendation framing (valence)

Menurut Cheung, Luo, Sia, dan Chen (2009) recommendation framing berkaitan dengan valence eWOM, entah itu dikelompokkan secara positif (contoh: pujian) atau secara negatif (contoh: complaint).

5. Recommendation sidedness

Menurut Cheung, Luo, Sia dan Chen (2009) recommendation sidedness berkaitan dengan 
sudut pandang, yang mana pesan satu sisi merepresentasikan fitur positif atau negatif dari produk atau jasa namun tidak keduanya, sedangkan pesan dua sisi menampilkan elemen positif dan negatif di dalamnya.

6. Volume review

Menurut Davis dan Khazanchi (2008), volume mengukur jumlah total dari interaksi WOM.

7. Disconfirming information

Menurut Watts dan Zhang (2008), disconfirming information merujuk pada konten informasi dalam pesan yang baru diterima tidak sesuai dengan pemahaman dan kepercayaan yang terdahulu.

8. Kekuatan argumen

Kekuatan argumen berkaitan dengan kekuatan atau sejauh mana argumen atau informasi tersebut masuk akal serta sejauh mana penerima informasi merasa sebuah argument valid dan meyakinkan (Luo et al., 2015).

9. Konsistensi rekomendasi

Menurut Cheung, Luo, Sia, dan Chen (2009) konsistensi rekomendasi mengindikasikan sejauh mana rekomendasi eWOM saat ini mirip dan cocok dengan pengalaman kontributor review terkait evaluasi produk atau jasa yang sama.

10. Recommendation rating

Menurut Cheung, Luo, Sia, dan Chen (2009) recommendation rating mengindikasikan skor (rating) yang diberikan oleh pembaca lain mengenai rekomendasi eWOM.

11. Panjang review

Menurut Chevalier dan Mayzlin (2006) panjang review berkaitan dengan total jumlah karakter yang ditulis oleh penulis review.

12. Visual cue

Menurut Davis dan Khazanchi (2008) visual cue dapat didefinisikan sebagai gambar (sebagai bentuk komunikasi) yang dipublikasikan oleh penulis review dan ditujukan pada konsumen lain untuk mengevaluasi karakteristik produk atau jasa tertentu, memberikan gambaran dan memperkaya informasi.

13. Penyebaran (dispersion)

Menurut Dellarocas, Zhang, dan Awad (2007), dispersion adalah seberapa cepat eWOM tersebar di komunitas yang berbeda.

\section{Pemilihan Hotel di OTA}

Peneliti melihat dari penelitian terdahulu yang terkait dengan pemilihan hotel di situs OTA agar mendapatkan gambaran dan penjelasan fenomena yang lebih jelas.
Penelitian yang pertama adalah penelitian tentang sejauh mana recommendation consistency memiliki kontribusi bagi konsumen memilih suatu produk atau jasa. Menurut Senecal dan Nantel (2004), responden yang menggunakan rekomendasi cenderung memilih produk yang direkomendasikan dua kali lebih sering daripada responden yang tidak mengkonsultasikan rekomendasinya. Selain itu rekomendasi secara online lebih berpengaruh daripada sumber rekomendasi tradisional dari para pakar.

Konsumen tidak hanya dipengaruhi oleh konsistensi rekomendasi saja, Vermeulen dan Seegers (2009) menyatakan review positif maupun negatif dapat meningkatkan kesadaran konsumen terhadap suatu hotel, terlebih lagi review positif mampu meningkatkan pendirian konsumen terhadap hotel, namun efek ini lebih kuat pada hotel-hotel yang kurang dikenal konsumen. Sidali, Schulze dan Spillera (2009) juga menambahkan bahwa kepercayaan dalam e-reviewmemiliki pengaruh positif dan signifikan terhadap pilihanakomodasi.

Perilaku konsumen ketika menggunakan media online dan media sosial dapat mempengaruhi proses pemilihan hotel. Penelitian McCarthy, Stock dan Verma (2010), menunjukkan business traveler seringkali menggunakan hotel yang direkomendasikan oleh perusahaan, rekomendasi dari teman atau kolega tidak begitu penting bagi business traveler, namun untuk leisure traveler hal ini berlaku sebaliknya.

\section{Kerangka Berpikir}

Berikut gambaran dari kerangka berpikir penelitian ini.

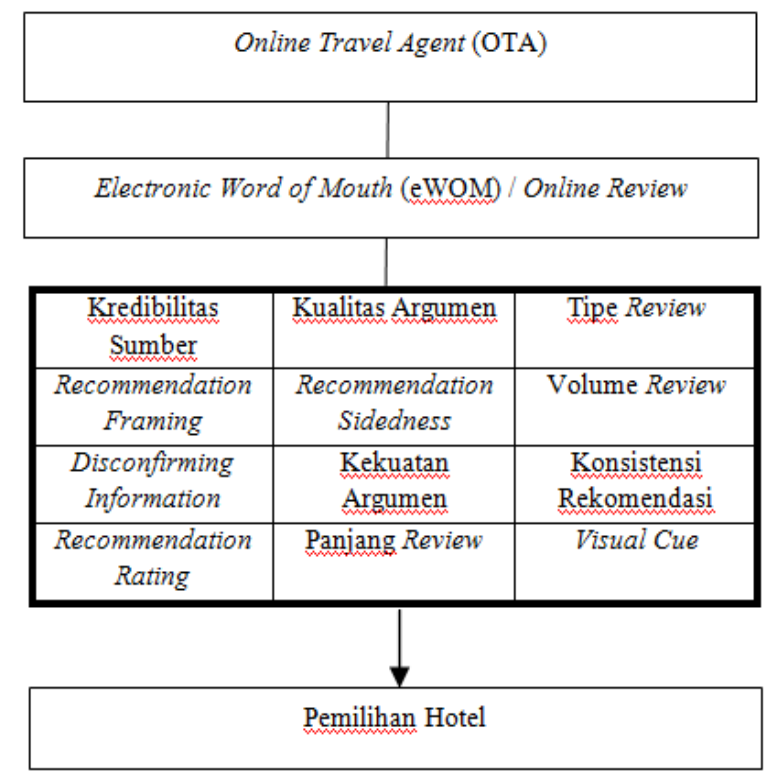

Gambar 1.Kerangka Berpikir 
Dimensi penyebaran tidak dianalisa lebih lanjut karena tidak sesuai dengan karakteristik OTA.

\section{METODE PENELITIAN}

Peneliti membuat survei dengan google form. Survei kemudian akan disebarkan kepada 300 orang secara online melalui media sosial mulai dari tanggal 6 November 2015 sampai 12 November 2015. Hasil survei akan dianalisa dengan menggunakan analisis faktor. Tahapan yang akan dilakukan dalam analisis faktor adalah:

1. Tabulasi data pada data view

2. Pembentukan matriks korelasi

3. Ekstraksi faktor

4. Rotasi faktor

5. Penamaan faktor yang terbentuk

\section{Definisi Operasional Variabel}

1. Kredibilitas sumber

- Reputasi penulis review (dilihat dari jumlah review yang telah ditulis)

- Kepercayaan terhadap penulis review

- Kefamiliaran penulis terhadap hotel berdasarkan pengalaman

2. Kualitas argumen

- Adanya kata atau kalimat yang mengajak pembaca untuk menginap

- Kesesuaian informasi dalam review dengan kebutuhan pembaca

- Keterkinian tanggal penulisan review (tanggal penulisan review tidak jauh dari tanggal membaca)

- Kebenaran informasi atau argumen review

- Kelengkapan informasi dalam review

- Kedalaman informasi dalam review

- Keluasan informasi dalam review

- Ketepatan tata bahasa dan kalimat yang dipakai dalam review

3. Tipe review

- Evaluasi atribut hotel dengan pencantuman data objektif

- Evaluasi manfaat hotel dengan pencantuman data subjektif

4. Recommendation framing

- Penjelasan mengenai kelebihan hotel

- Penjelasan mengenai kelemahan hotel

5. Recommendation sidedness

- Penjelasan mengenai salah satu sisi (kelebihan atau kelemahan) hotel
- Penjelasan mengenai kedua sisi (kelebihan dan kelemahan) hotel

6. Volume review

- Jumlah review tentang hotel tersebut

7. Disconfiming information

- Kesamaan informasi antara review dan yang diketahui pembaca

8. Kekuatan argumen

- Informasi memiliki sifat meyakinkan

- Rasionalitas informasi dalam review (masuk akal)

9. Konsistensi rekomendasi

- Kemiripan (similarity) argumen satu review dengan yang lainnya

- Kecocokan argumen satu review dengan yang lainnya

10. Recommendation rating

- Banyakya pembaca yang setuju dengan isi review

11. Panjang review

- Banyaknya kata atau kalimat yang dipakai dalam review

\section{Visual cue}

- Pencantuman gambar atau foto pengalaman menginap penulis

\section{HASIL PENELITIAN}

\section{Deskripsi Karakteristik Responden}

Jumlah survei yang layak untuk dianalisis lebih lanjut dalam penelitian ini adalah 300 buah. Menurut hasil kuesioner, sebagian besar responden berjenis kelamin pria sebanyak 51\%. Berdasarkan usianya mayoritas responden berusia 17 sampai 30 tahun sebanyak 49\%. Mayoritas tingkat pendidikannya adalah sarjana sebanyak $74 \%$. Kebanyakan responden bekerja sebagai pegawai swasta sebanyak $35 \%$. Tingkat pendapatan responden paling banyak adalah Rp. 2.000.000 sampai Rp. 4.999 .999 per bulan sebanyak 29\%. Mayoritas responden berdomisili di Surabaya, sebanyak 37\%. Sebagian besar responden sering menggunakan OTA dalam memilih hotel sebanyak $51 \%$. Situs yang paling sering digunakan adalah traveloka.com sebanyak $49 \%$. Responden juga sering membaca review sebelum memilih hotel sebanyak $48 \%$. Intensitas responden menginap di hotel kebanyakan hanya 1 sampai 2 kali dalam setahun sebanyak $54 \%$. Hotel yang paling sering dipesan melalui OTA adalah hotel bintang 3 sebanyak $57 \%$. Tujuan menginap para responden adalah untuk tujuan wisata sebanyak $79 \%$. 


\section{Deskripsi Jawaban Responden}

Tabel 1.Nilai Mean dan Standar Deviasi Jawaban Responden

\begin{tabular}{|c|c|c|c|}
\hline No & Pernyataan & $\overline{\mathrm{X}}$ & $\sigma$ \\
\hline 1 & Reputasi penulis review & 3.84 & 1.081 \\
\hline 2 & Kepercayaan terhadap penulis review & 3.74 & 0.693 \\
\hline 3 & $\begin{array}{l}\text { Kefamiliaran penulis terhadap hotel } \\
\text { berdasarkan pengalaman }\end{array}$ & 3.74 & 0.781 \\
\hline \multicolumn{2}{|c|}{ Mean dimensi kredibilitas penulis } & 3.77 & 0.851 \\
\hline 4 & $\begin{array}{l}\text { Adanya kata atau kalimat yang } \\
\text { membujuk pembaca untuk menginap }\end{array}$ & 3.41 & 0.999 \\
\hline 5 & $\begin{array}{l}\text { Kesesuaian informasi dalam review } \\
\text { dengan kebutuhan pembaca }\end{array}$ & 3.80 & 0.876 \\
\hline 6 & Keterkinian tanggal penulisan review & 3.81 & 0.886 \\
\hline 7 & $\begin{array}{l}\text { Kebenaran informasi atau argumen } \\
\text { review }\end{array}$ & 3.88 & 0.955 \\
\hline 8 & Kelengkapan informasi review & 3.75 & 0.903 \\
\hline 9 & Kedalaman informasi review & 3.69 & 0.896 \\
\hline 10 & Keluasan informasi review & 3.62 & 0.863 \\
\hline 11 & $\begin{array}{l}\text { Ketepatan tata bahasa dan kalimat yang } \\
\text { dipakai dalam review }\end{array}$ & 3.14 & 0.876 \\
\hline \multicolumn{2}{|c|}{ Mean dimensi kualitas argumen } & 3.64 & 0.907 \\
\hline & $\begin{array}{l}\text { Evaluasi atribut hotel dengan } \\
\text { pencantuman data obyektif }\end{array}$ & 3.74 & 0.907 \\
\hline 13 & $\begin{array}{l}\text { Evaluasi manfaat hotel dengan } \\
\text { pencantuman data subyektif }\end{array}$ & 3.73 & 0.898 \\
\hline \multicolumn{2}{|c|}{ Mean dimensi tipe review } & 3.73 & 0,902 \\
\hline 14 & Penjelasan mengenai kelebihan hotel & 3.55 & 0.911 \\
\hline 15 & Penjelasan mengenai kelemahan hotel & 3.63 & 0.953 \\
\hline \multicolumn{2}{|r|}{ Mean dimensi recommendation framing } & 3.59 & 0.932 \\
\hline & $\begin{array}{l}\text { Penjelasan mengenai salah satu sisi } \\
\text { (kelebihan atau kelemahan) hotel }\end{array}$ & 3.56 & 0.885 \\
\hline 17 & $\begin{array}{l}\text { Penjelasan mengenai kedua sisi } \\
\text { (kelebihan dan kelemahan) hotel }\end{array}$ & 3.86 & 0.838 \\
\hline \multicolumn{2}{|c|}{ Mean dimensi recommendation sidedness } & 3.71 & 0.861 \\
\hline 18 & Jumlah review tentang hotel tersebut & 3.59 & 0.923 \\
\hline 19 & $\begin{array}{l}\text { Kesamaan informasi antara review dan } \\
\text { yang saya ketahui }\end{array}$ & 3.59 & 0.919 \\
\hline 20 & Sifat informasi yang meyakinkan & 3.73 & 0.864 \\
\hline 21 & Rasionalitas informasi review & 3.78 & 0.818 \\
\hline \multicolumn{2}{|c|}{ Mean dimensi kekuatan argumen (no. 20-21) } & 3.75 & 0.841 \\
\hline 22 & $\begin{array}{l}\text { Kemiripan argumen satu review dengan } \\
\text { yang lainnya }\end{array}$ & 3.61 & 0.868 \\
\hline 23 & $\begin{array}{l}\text { Kecocokan argumen satu review dengan } \\
\text { yang lainnya }\end{array}$ & 3.64 & 0.868 \\
\hline \multicolumn{2}{|c|}{ Mean dimensi konsistensi rekomendasi } & 3.62 & 0.868 \\
\hline 24 & $\begin{array}{l}\text { Banyakya pembaca yang setuju dengan } \\
\text { isi review }\end{array}$ & 3.46 & 0.904 \\
\hline 25 & $\begin{array}{l}\text { Banyaknya kata atau kalimat yang } \\
\text { dipakai dalam review }\end{array}$ & 3.04 & 0.967 \\
\hline 26 & $\begin{array}{l}\text { Pencantuman gambar atau foto } \\
\text { pengalaman menginap penulis }\end{array}$ & 3.68 & 0.902 \\
\hline
\end{tabular}

\section{Analisis Faktor}

Analisis faktor pada penelitian ini digunakan untuk mengetahui faktor-faktor apa saja yang penting dan paling berkontribusi bagi konsumen dalam memilih hotel di situs OTA.Setelah data ditabulasi, maka langkah selanjutnya adalah melakukan uji Kaiser-Meyer-Olkin Measure of Sampling Adequacy (KMO) dan Bartlett's Test of Sphericity.

Dari uji KMO diketahui bahwa nilai MSA sebesar $0.946>0.6$, sehingga dapat disimpulkan bahwa variabel-variabel yang digunakan dalam pene- litian lebih lanjut. Bartlett's Test menunjukkan nilai signifikansi sebesar $0.000<0.05$ maka dapat disimpulkan bahwa variabel-variabel tersebut saling berkorelasi dan sesuai untuk dianalisis faktor.

Variabel-variabel ini selanjutnya akan diekstrak sehingga terbentuk satu atau lebih faktor. Berdasarkan nilai eigenvalue dapat diketahui terdapat 4 faktor yang terbentuk, dengan nilai sebesar 11.287, 1.870, 1.397, dan 1.027. Namun peneliti memutuskan hanya menggunakan 3 faktor untuk memperoleh hasil yang lebih efektif.

Langkah selanjutnya adalah merotasi faktorfaktor yang terbentuk. Pendekatan oblique rotation digunakan untuk merotasi faktor-faktor ini dengan metode oblimin.

Langkah terakhir dalam analisis faktor yaitu pemberian nama pada 3 faktor baru yang telah terbentuk, yaitu: isi review, kredibilitas penulis, yang terakhir adalah cara penulisan dan recommendation rating. Besar kontribusi faktor yang penting bagi konsumen dalam memilih hotel di situs OTA adalah: isi review (43.411\%), kredibilitas penulis $(7.191 \%)$, serta yang terakhir cara penulisan dan recommendation rating $(5.372 \%)$.

Tabel 2.Tabel Faktor Baru

\begin{tabular}{|c|c|c|}
\hline No & Nama Faktor & Komponen faktor / variabel \\
\hline 1 & Isi review & $\begin{array}{l}\text { Evaluasi atribut hotel dengan pencantuman } \\
\text { data obyektif } \\
\text { Penjelasan mengenai kedua sisi hotel } \\
\text { Penjelasan mengenai kelemahan hotel } \\
\text { Kelengkapan informasi review } \\
\text { Sifat informasi yang meyakinkan } \\
\text { Penjelasan mengenai salah satu sisi hotel } \\
\text { Kebenaran informasi atau argumen review } \\
\text { Evaluasi manfaat hotel dengan } \\
\text { pencantuman data subyektif } \\
\text { Rasionalitas informasi review } \\
\text { Penjelasan mengenai kelebihan hotel } \\
\text { Kesesuaian informasi dalam review denan } \\
\text { kebutuhan pembaca } \\
\text { Kedalaman informasi review } \\
\text { Kesamaan informasi antara review dan } \\
\text { yang saya ketahui } \\
\text { Keluasan informasi review } \\
\text { Jumlah review tentang hotel tersebut } \\
\text { Kecocokan argumen satu review dengan } \\
\text { yang lainnya } \\
\text { Pencantuman gambar atau foto } \\
\text { pengalaman menginap penulis } \\
\text { Keterkinian tanggal penulisan review } \\
\text { Kemiripan argumen satu review dengan } \\
\text { yang lainnya }\end{array}$ \\
\hline 2 & $\begin{array}{l}\text { Kredibilitas } \\
\text { penulis }\end{array}$ & $\begin{array}{l}\text { Reputasi penulis review } \\
\text { Kepercayaan terhadap penulis review } \\
\text { Kefamiliaran penulis terhadap hotel } \\
\text { berdasarkan pengalaman }\end{array}$ \\
\hline 3 & $\begin{array}{l}\text { Cara penulisan } \\
\text { dan recommen- } \\
\text { dation rating }\end{array}$ & $\begin{array}{l}\text { Banyaknya kata atau kalimat yang dipakai } \\
\text { dalam review } \\
\text { Banyaknya pembaca yang setuju dengan } \\
\text { isi review } \\
\text { Adanya kata atau kalimat yang membujuk } \\
\text { pembaca untuk menginap } \\
\text { Ketepatan tata bahasa dan kalimat yang } \\
\text { dipakai dalam review }\end{array}$ \\
\hline
\end{tabular}




\section{Pembahasan}

Hasil survei responden menyatakan bahwa seluruh responden membuat pemesanan hotel melalui situs OTA. Kemudahan dan keragaman pilihan yang ditawarkan oleh OTA menyebabkan responden cenderunglebih suka untuk menggunakan OTA dibandingkan channel lainnya seperti offline travel agent.

Usia seseorang juga dapat mempengaruhi preferensi pembaca dalam membaca review. Menurut Gretzel dan Yoo (2008), konsumen yang berusia 65 tahun ke atas lebih sedikit membaca dan menggunakan review dalam proses perencanaan perjalanan daripada mereka yang berusia 18 sampai 34 tahun. Penelitian tersebut mendukung hasil survei penelitian ini yang mana pengguna OTA dan pembaca review terbanyak berasal dari responden yang berusia 17 sampai 30 tahun.

Berdasarkan hasil analisis faktor, faktor isi review memiliki kontribusi paling besar paling besar, artinya isi review merupakan faktor yang paling penting bagi konsumen dalam memilih hotel.Hal ini disebabkan oleh dalam tahap awal pemilihan hotel, konsumen cenderung untuk mengumpulkan informasi terlebih dahulu.Salah satu sumber informasi yang ada pada OTA adalah review. Hennig-Thurau dan Walsh (2003) menyatakan bahwa konten informasi review dinilai penting bagi konsumen karena dapat membantu konsumen untuk membuat keputusan yang lebih baik dan dapat mengurangi waktu pencarian informasi, serta dapat membantu konsumen untuk membandingkan pengalaman yang dirasakan konsumen lain ketika mengonsumsi suatu produk atau jasa.

Besarnya kontribusi pada faktor isi review juga didukung oleh nilai mean komponen faktor yang tinggi. Nilai mean paling tinggi merupakan kebenaran review. Cara pandang konsumen mengenai kebenaran informasi membutuhkan konfirmasi konsumen untuk mengetahui apakah suatu argumen benar atau salah, sehingga informasi akan dianggap benar jika cocok dengan apa yang telah diketahui konsumen sebagai fakta (Cheung, Lee \& Rabjohn, 2008).

Nilai mean terbesar kedua adalah penjelasan mengenai kedua sisi hotel. Penjelasan mengenai dua sisi (kelebihan dan kelemahan) dianggap lebih penting daripada hanya satu sisi. Kredibilitas informasi dapat meningkat ketika sebuah review memiliki dua sisi, hal ini disebabkan karena pembaca merasa penulis menuliskan hal yang sebenarnya, tidak mengada-ada untuk mempromosikan suatu hotel (Purnawirawan, De Pelsmacker, Dens, \& Eisend, 2015).
Faktor kedua yang juga penting bagi konsumen adalah kredibilitas penulis. Kredibilitas penulis juga dapat memperkuat persepsi konsumen apabila konsumen merasa konten informasi review tersebut meyakinkan (Zhang, Zhao, Cheung \& Lee, 2014). Kredibilitas penulis sangat ditentukan oleh persepsi konsumen, karena siapapun dapat menulis review dengan bebas, sehingga semuanya tergantung pada bagaimana konsumen menilai sebuah sumber atau penulis (Cheung, Lee \& Rabjohn, 2008).

Faktor ketiga memiliki kontribusi paling kecil, yang berarti cara penulisan dan recommendation rating pada review dinilai tidak begitu penting bagi konsumen dalam memilih hotel. Hal ini didukung pula oleh nilai meanyang rendahpada hasil jawaban responden.Tingkat persuasif suatu review ditentukan oleh isi dari review, bukan dari ada atau tidaknya kalimat yang membujuk. Ketepatan tata bahasa juga dirasa kurang penting karena konsumen cenderung lebih mementingkan isi. Sedangkan banyaknya kata atau kalimat dalam review hanya berkaitan dengan antusiasme penulis dalam membagikan pengalamannya (Chevalier \& Mayzlin, 2006). OTA yang paling sering digunakan menurut penelitian ini adalah traveloka.com dan agoda.com, namun kedua OTA ini tidak memiliki fitur recommendation rating. Akibatnya konsumen tidak pernah menggunakan fitur rating tersebut, dan akhirnya dinilai tidak penting.

Total kontribusi dari ketiga faktor adalah 55.974\%. Angka tersebut menunjukkan besarnya kontribusi review dalam bagi konsumen dalam pemilihan hotel. Hal ini menunjukkan bahwa review sangat berpengaruh bagi konsumen, walaupun juga terdapat $44.026 \%$ variabel lainnya yang juga mempengaruhi konsumen dalam memilih hotel di OTA seperti harga, brand, kategori bintang hotel, fasilitas hotel dan lain-lain.

\section{Implikasi Managerial}

Isi review merupakan salah satu sumber informasi yang dapat digunakan konsumen dalam menentukan hotel mana yang akan dipilih, sehingga pihak hotel sebaiknya memperhatikan review yang tertulis pada OTA, terutama review yang bersifat negative. Selain itu, OTA yang sering digunakan oleh masyarakat Indonesia adalah traveloka.com dan agoda.com yang tidak memfasilitasi hotel untuk membalas review. Akibatnya, pihak hotel tidak dapat menulis klarifikasi maupun permintaan maaf di OTA maupun menghapus review negatif yang sudah muncul. Oleh karena itu, hotel harus dapat melakukan antisipasi terhadap review negatif. Ketika review tersebut telah dipublikasi, maka akan lebih sulit untuk 
mengangkat kembali reputasi hotel tersebut. Purnawirawan, De Pelsmacker, Eisend, dan Dens (2015) menyarankan sebisa mungkin pihak hotel menyelesaikan keluhan yang diutarakan oleh konsumen pada saat konsumen masih menginap di hotel untuk mengurangi munculnya review yang bersifat negatif di OTA. Salah satu hal yang dapat dilakukan adalah dengan menanyakan kesan para tamu mengenai pengalaman menginapnya pada saat proses check-out. Dengan demikian hotel dapat memperoleh informasi mengenai performa hotel dan dapat melakukan recovery pada saat itu juga.Berdasarkan observasi peneliti keluhan-keluhan yang banyak muncul pada review di OTA adalah karyawan kurang profesional sehingga lama dalam memberikan pelayanan dan masalah kebersihan. Untuk mengurangi keluhan mengenai pelayanan, hotel dapat memberikan pelatihan-pelatihan bagi karyawannya sehingga karyawannya semakin terampil dalam memberikan pelayanan. Pengecekan secara berkala dan konsisten perlu digiatkan untuk menjaga kebersihan hotel, serta pemakaian form dan checklist pengecekan akan membantu sebagai alat dalam mengontrol kebersihan hotel.

Hasil penelitian ini menunjukkan bahwa kebanyakan konsumen hotel yang membaca review sebelum memilih hotel adalah usia 17-30 tahun. Hal ini dapat menjadi perhatian hotel yang memiliki target pasar konsumen yang berusia muda. Purnawirawan, De Pelsmacker, Eisend dan Dens (2015) menyatakan pihak hotel dapat mendorong tamu-tamu hotelnya untuk menuliskan pengalaman menginap mereka di OTA, sehingga dapat menyediakan informasi bagi konsumen lain, mempromosikan brand hotel itu sendiri, dan dapat membujuk konsumen lain (pembaca). Dalam rangka mendorong konsumen menulis review, pihak hotel juga dapat memberikan reward apabila konsumen bersedia menulis review di OTA. Ketika hotel mampu banyak konsumen yang menulis review tentang hotel tersebut, maka pihak hotel juga dapat menjaga review tetap up to date.

Kredibilitas penulis juga dinilai penting bagi konsumen. Pihak OTA sebaiknya memperhatikan kebutuhan pembaca atau konsumen akan informasi identitas penulis review. OTA biasanya hanya mencantumkan nama penulis, dan nama yang digunakan oleh penulis seringkali tidak dapat digunakan untuk mengidentifikasi identitas yang sebenarnya. Menurut Ayeh, Au, dan Law (2008) OTA dapat bekerjasama dengan pihak media sosial untuk mengotentikasi review yang ditulis di OTA, misalnya dengan mengharuskan penulis untuk login menggunakan profil facebook.

\section{KESIMPULAN DAN SARAN}

\section{Kesimpulan}

Ada 3 faktor yang penting bagi konsumen dalam memilih hotel di situs OTA yaitu isi review, kredibilitas penulis serta cara penulisan dan recommendation rating. Diantara 3 faktor yang ada isi review adalah faktor yang paling berkontribusi bagi konsumen dalam memilih hotel di OTA.

\section{Saran}

Adapun saran yang dapat diberikan sebagai hasil penelitian ini adalah sebagai berikut: Berdasarkan penelitian, isi review sangat penting bagi konsumen dalam pemilihan hotel, sehingga pihak hotel perlu memperhatikan review yang muncul terutama yang negatif di OTA dan menjaganya untuk tetap up to date bagi target pasarnya. Selain itu pihak OTA juga dapat meningkatkan kredibilitas penulis dengan cara bekerja sama dengan pihak sosial media dalam mengotentikasi identitas.

\section{DAFTAR PUSTAKA}

Ayeh, J. K., Au, N., \& Law, R. (2013). "Do we believe in TripAdvisor?" Examining credibility perceptions and online travelers' attitude toward using user-generated content.Journal of Travel Research, 52(4), 437-452.

Brynjolfsson, E., \& Smith, M. D. (2000). Frictionless commerce? A comparison of internet and conventional retailers. Management science, 46(4), 563-585.

Cheung, C. M., Lee, M. K., \& Rabjohn, N. (2008). The impact of electronic word of mouth. Internet Research, 18(3), 229-247.

Cheung, M., Luo, C., Sia, C. \& Chen, H. (2009). Credibility of electronic word of mouth: Informational and normative determinants of on-line consumer recommendations. International Journal of Electronic Commerce, 13(4), 9-38.

Cheung, C. M., \& Thadani, D. R. (2010). The effectiveness of electronic word of mouth communication: A literature analysis. Proceedings of the 23rd Bled eConference eTrust: Implications for the Individual, Enterprises and Society, 329345.

Chevalier, J. A., \& Mayzlin, D. (2006). The effect of word of mouth on sales: Online book review. Journal of Marketing Research, 43(3), 345-354.

Davis, A., \& Khazanchi, D. (2008). An empirical study of online word of mouth as predictor for multiproduct category e-commerce sales. Electronic markets, 18(2), 130-141. 
Dellarocas, C., Zhang, X. M., \& Awad, N. F. (2007). Exploring the value of online product reviews in forecasting sales: The case of motion pictures. Journal of Interactivemarketing, 21(4),23-45.

Gretzel, U., \& Yoo, K. H. (2008). Use and impact of online travel reviews. Information and Coтmunication Technologies in Tourism 2008, 8(2), 35-46.

Grewal, D., Munger, J. L., Iyer, G. R., \& Levy, M. (2003). The influence of internet-retailing factors on price expectations. Psychology \& Marketing, 20(6), 477-493.

Hennig-Thurau, T., Gwinner, K. P., Walsh, G., Gremler, D. D. (2004). Electronic word of mouth via consumer opinion platforms: What motivates consumers to articulate themselves on the internet?. Journal of Interactive Marketing, 18(1), 38-52.

Hennig-Thurau, T., Walsh, G., \& Walsh, G. (2003). Electronic word of mouth: Motives for and consequences of reading customer articulations on the Internet. International Journal of Electronic Commerce, 8(2), 51-74.

Jansen, B. J., Zhang, M., Sobel, K., \&Chowdury, A. (2009). Twitter power: Tweets as electronic word of mouth. Journal of the American Society for Information Science and Technology, 60(11), 2169-2188.

Kiecker, P., \& Cowles, D.L. (2001). Interpersonal communication and personal influence on the Internet: A framework for examining online word of mouth. Journal of Euromarketing, 11(2), 71-88.

Luo, C., Luo, X. R., Xu, Y., Warkentin, M., \& Sia, C. L. (2015). Examining the moderating role of sense of membership in online review evaluations.Information \& Management, 52(3), 305316.

McCarthy, L., Stock, D., \& Verma, R. (2010). How travelers use online and social media channels to make hotel-choice decisions. Cornell Hospitality Report, 10(18), 1-24.

Park, D. H., \& Kim, S. (2008). The effectsof consumer knowledge on message processing of electronic word of mouth via online consumer reviews. Electronic Commerce Research and Applications, 7(4), 399-410.
Peterson, R.A., \& Merino, M.C. (2003). Consumer information search behavior and the Internet. Psychology \& Marketing, 20(2), 99-121.

Senecal, S., \& Nantel, J. (2004). The influence of online product recommendations on consumers' online choices.Journal of retailing, 80(2), 159169.

Purnawirawan, N., De Pelsmacker, P., Dens, N. \& Eisend, M. (2015). A meta-analytic investigation of the role of valence in online reviews.Journal of Interactive Marketing, 31, 17-27.

Rizkia, C. (2015, September 30). Tahun depan, pembeli online di Indonesia capai 8,7 juta orang. Selular.ID. Retrieved February 12, 2016, from http://selular.id/news/e-ommerce/2015/09/tahundepan-pembeli-online-di-indonesia-capai-87juta-orang/

Short, T. (2014, June 11). Survey: how travelers use online hotel reviews. Software Advice.Retrieved September 18, 2015, from http://overnightsuccess.softwareadvice.com/survey-howtravelers-use-online-hotel-reviews-0614/.

Sidali, K. L., Schulze, H., \& Spiller, A. (2009).The impact of online reviews on the choice of holiday ccommodations. Information and Communication Technologies in Tourism 2009, 8798.

Teng, S., Wei Khong, K., Wei Goh, W., \& Yee Loong Chong, A. (2014). Examining the antecedents of persuasive eWOM messages in social media. Online Information Review, 38(6), 746-768.

Vermeulen, I. E., \& Seegers, D. (2009). Tried and tested: The impact of online hotel reviews on consumer consideration. Tourism Management, 30(1), 123-127.

Watts, S. A., \& Zhang, W. (2008). Capitalizingon content: Information adoption in two online communities. Journal of the Association for Information Systems, 9(2), 73-94.

Zhang, K. Z., Zhao, S. J., Cheung, C. M., \& Lee, M. K. (2014). Examining the influence of online reviews on consumers' decisionmaking: A heuristic-systematic model. Decision Support Systems, 67, 78-89. 